A RCHIWA, BIBLIOTEKI

I MUZEA KOŚCIELNE 111 (2019)

https://doi.org.10.31743/abmk.2019.111.07

KS ANDRZEJ KOPICZKO* - OLSZTYN

\title{
PARAFIA I KOŚCIÓŁ W ORNECIE W ŚWIETLE PROTOKOŁU POWIZYTACYJNEGO Z 1798 R.
}

\section{Streszczenie}

Podstawę źródłową artykułu stanowi protokół powizytacyjny parafii w Ornecie z 1798 r., spisany w języku łacińskim. Zawiera on informacje o początkach kościoła i jego wyposażeniu. Szczegółowo opisano w nim ołtarze i kaplice, chrzcielnicę i zakrystię. Odnotowano porządek nabożeństw oraz działające bractwa. Do przyjmowania Komunii Św. wielkanocnej zobowiązanych było 2500 osób, ale do miejscowego kościoła przybywali też katolicy z protestanckich Prus, w liczbie ok. 400. Na terenie parafii mieszkało jeszcze 60 luteranów, którym odprawiano nabożeństwa w gmachu magistratu. $\mathrm{W}$ protokole podano podstawowe dane biograficzne proboszcza ks. Tadeusza Orlikowskiego oraz trzech wikariuszy: ks. Antoniego Rehana, ks. Franciszka Wegnera i ks. Jana Kolberga. Wizytator sprawdził funkcjonowanie szkoły, podał nazwiska nauczyciela (Franciszka Eckerta) i kantora (Andrzeja Eckerta) oraz liczbę uczniów (90 chłopców). W mieście funkcjonowała jeszcze placówka prowadzona przez siostry katarzynki, w której 86 dziewcząt uczyło się czytania, pisania, prawd wiary oraz robótek ręcznych. Z pracowników kościelnych odnotowano także organistę (Antoniego Krohnenbergera), kościelnego (Jana Kolessa), grabarza (Jakuba Brauna) oraz akuszerki. Z instytucji parafialnych opisano dwa szpitale (Ducha Świętego i św. Jerzego). Dużo miejsca w protokole zajmuje kwestia uposażenia kościoła. Wiele z podanych w protokole informacji, zwłaszcza personalnych, nie było dotychczas odnotowanych w literaturze, zatem uzupełniają one w sposób znaczący naszą wiedzę o orneckiej parafii i tamtejszej świątyni.

Słowa kluczowe: diecezja warmińska; Orneta; parafia; kościół; zabytki; duszpasterze; pracownicy kościelni

* Ks. Andrzej Kopiczko - prof. historii; Wydział Humanistyczny; Uniwersytet Warmińsko-Mazurski w Olsztynie; e-mail: andrzejkopiczko@wp.pl

https://orcid.org/0000-0002-9834-2433 
Protokoły wizytacji parafialnych są doskonałym źródłem do poznania nie tylko dziejów kościelnych, lecz także życia społecznego lokalnych środowisk. Zawierają bardzo cenne informacje dotyczące wyposażenia świątyń, duszpasterstwa, instytucji i grup przykościelnych, duchowieństwa i pracowników świeckich oraz uposażenia. W przypadku parafii w Ornecie takimi dokumentami dysponujemy już od drugiej połowy XVI wieku. W naszych analizach skoncentrujemy się na protokole mało znanym i prawie w ogóle niewykorzystywanym w opracowaniach poświęconych tej wspólnocie parafialnej, a - jak się okazuje - bogatym w nowe treści. Przechowywany jest on w Archiwum Archidiecezji Warmińskiej w Olsztynie. Został sporządzony w języku łacińskim na papierze czerpanym, pochodzącym z papierni w Osetniku ze znakiem wodnym „IS WUSEN"1. Posiada tekturową oprawę i wymiary: $35 \mathrm{~cm}$ wysokości, $21 \mathrm{~cm}$ szerokości oraz $1 \mathrm{~cm}$ grubości.

Świątynia w Ornecie jest jednym z najcenniejszych i najstarszych zabytków kościelnego budownictwa gotyckiego na Warmii. Zaczęto ją wznosić w połowie XIV wieku, a konsekrowano w 1379 roku. Nadano jej formę krótkiej bazyliki bezchórowej. Od końca XIV wieku do naw bocznych zaczęto dostawiać tej samej wysokości kaplice, dzięki czemu całość budowli zamknęła się w obrysie regularnego prostokąta. Niezwykle bogate jest wnętrze świątyni. Przykrywają ją wielogwiaździste sklepienia nawy głównej, które zbudowano przed 1494 rokiem. Z XV wieku pochodzą też gotyckie freski. Większość jednak wyposażenia datuje się na XVII i XVIII wiek. Najstarszy proboszcz tej parafii, Henryk, został odnotowany 11 lutego 1312 roku, a kolejny, Albert, 1 stycznia 1326 roku. Kośció od początku był siedzibą archiprezbiteratu (dekanatu), do którego w okresie nowożytnym należało 11 parafii. W latach 1340-1349 w Ornecie rezydował biskup warmiński Herman z Pragi².

Analizowaną wizytację przeprowadził w 1798 roku na polecenie biskupa Karola Hohenzollerna kanonik Warmińskiej Kapituły Katedralnej, ks. Jan Alojzy de Melitz ${ }^{3}$. Na początku analizowanego protokołu zostały przypomniane zalecenia soboru trydenckiego odnośnie do wizytacji. Biskup wyjaśnił też, dlaczego sam nie podjął się tego obowiązku (słabe zdrowie) i stąd wyznaczył zastępcę. Dołączono również kwestionariusz wizytacji z pytaniami ${ }^{4}$. Miała

${ }^{1}$ Tymi inicjałami posługiwał się papiernik Josef Hempel w latach 1789-1797. A. Ulewicz, J. Dąbrowski, Filigrany w zasobie Archiwum Państwowego w Olsztynie, Olsztyn 2018, s. 100.

${ }^{2}$ Rocznik Diecezji Warmińskiej, Olsztyn 1985, s. 382-383; A. Kopiczko, Ustrój i organizacja diecezji warmińskiej $w$ latach 1525-1772, Olsztyn 1993, s. 382-383; A. Kopiczko, Kościoly jubileuszowe i sanktuaria Świętego Krzyża w archidiecezji warmińskiej, Olsztyn 2002, s. 79-84.

${ }^{3}$ Ur. 9 VIII 1752 r. w Leginach. W 1763 r. podjął naukę w gimnazjum jezuickim w Reszlu. Kapelan biskupa Ignacego Krasickiego. W 1776 r. ustanowiony proboszczem w Wilczkowie. Od 1791 r. koadiutor kanonika Marcina Krasickiego w Kapitule fromborskiej, a po jego śmierci w 1792 r. - kanonik rzeczywisty. W 1801 r. zrezygnował z parafii w Wilczkowie. Zm. 21 VIII 1803 r. A. Kopiczko, Duchowieństwo katolickie diecezji warmińskiej w latach 15251821, cz. 2, Olsztyn 2000, s. 217-218.

${ }^{4}$ Archiwum Archidiecezji Warmińskiej w Olsztynie (dalej: AAWO), Archiwum Biskupie (dalej: AB), sygn. B 47, k. 1-4v. 
ona objąć cały archiprezbiterat ornecki, dlatego powiadomienia i informacje o terminach przesłano do wszystkich proboszczów z wyznaczonego terenu ${ }^{5}$. Uczynił to sam ks. Jan de Melitz z Fromborka 15 czerwca 1798 roku. Już następnego dnia archiprezbiter ornecki, ks. Tomasz Orlikowski, potwierdził, iż pismo to otrzymał. Rozpoczęcie wizytacji zaplanowano na 26 września 1798 roku w kościele archiprezbiterialnym ${ }^{6}$. Wizytator poprosił także o przygotowanie protokołów z poprzednich wizytacji oraz ważniejszych dokumentów i rachunków, dotyczących dochodów i rozchodów w parafiach. Ponadto zalecił, by informację o wizytacji wpisać do księgi procesów, a kopię powiadomienia umieścić na drzwiach kościoła, by wszyscy mogli się dowiedzieć o tym wydarzeniu?

Do Ornety wizytator ks. Jan de Melitz przybył - jak zaplanowano 26 września. Tam został powitany przez duchowieństwo i magistrat na plebanii o godz. 8.00, a następnie ze wszystkimi udał się do kościoła, gdzie odprawił Mszę za parafian. Wizytację rozpoczął od ogólnego sprawdzenia tabernakulum, potem ołtarzy, chrzcielnicy i paramentów liturgicznych. Jak zapisał - wszystko było w należytej czystości i porządku.

O kościele parafialnym zanotował, że zaczęto go wznosić w połowie XIV wieku (w protokole, że ok. 1300 roku), a konsekrował go w 1379 roku biskup warmiński Henryk III Sorbom ku czci Boga Wszechmogącego, Chwalebnej Dziewicy Maryi i św. Jana Ewangelisty ${ }^{8}$. Po raz drugi konsekracja miała miejsce - jak napisano w protokole, z powodu jakiegoś znieważenia, może przez heretyków - w 1494 roku przez biskupa pomocniczego płockiego Jakuba, za zgodą biskupa warmińskiego Łukasza Watzenrodego. Wówczas patronami kościoła zostali św. Jan Chrzciciel i Jan Ewangelista9. Natomiast na patronkę całej parafii i miasta obrano św. Elżbietę $\left(\right.$ wdowę $\left.^{10}\right) \mathrm{i}-\mathrm{z}$ powodu wielu pożarów - św. Wawrzyńca (męczennika). Uroczystość patronalna św. Jana Ewangelisty odbywała się w dzień wspomnienia, natomiast św. Jana Chrzciciela, św. Elżbiety i św. Wawrzyńca były przenoszone na najbliższą niedzielę. Kościół otrzymał też od Stolicy Apostolskiej 30 stycznia 1795 roku na 10 lat przywilej odpustu w uroczystość św. Jana Chrzciciela i św. Jana Ewangelisty. Został on ogłoszony przez kanonika warmińskiego, ówczesnego administratora diecezji warmińskiej, ks. Karola Poeppelmanna ${ }^{11}$.

Kościół ornecki został zbudowany z cegły, ze sklepieniem opartym na 6 filarach, z 3 nawami (środkowa wyższa, a boczne niższe). $Z$ powodu wielu kaplic po stronie południowej i północnej oraz osobnych dachów wymagał

\footnotetext{
${ }^{5}$ Tamże, k. 7.

${ }^{6}$ Tamże, k. 8.

${ }^{7}$ Tamże, k. $8 \mathrm{v}$.

${ }^{8}$ Ogólne informacje i bibliografia, zob. Rocznik Diecezji Warmińskiej, s. 382-383.

${ }^{9}$ Codex Diplomaticus Warmiensis oder Regesten und Urkunden zur Geschichte Ermlands, t. 3: Urkunden der Jahre 1376-1424 nebst Nachträgen, wyd. C.P. Woelky, Braunsberg-Leipzig 1874 (dalej: CDW III), s. 56-57 (nr 84).

${ }^{10}$ Chodzi o św. Elżbietę Węgierską, ur. w 1207 r. w Bratysławie jako trzecie dziecko Andrzeja II, króla Węgier, i Gertrudy, siostry św. Jadwigi Śląskiej. Zm. w 1231 r.

${ }^{11}$ Kopiczko, Duchowieństwo katolickie, s. 250.
} 
częstych napraw, ale w czasie wizytacji nie był narażony na zacieki. Posadzka została wyłożona w 1711 roku z ciosanych kamieni, a płyty grobowe wyjęto i umieszczono w nawie środkowej (napisy były już nieczytelne).

Dzwonnica znajduje się po stronie zachodniej kościoła. Zbudowano ją na planie kwadratu. W czasie wizytacji wisiało w niej 5 dzwonów. Jeden z nich, określony jako duży, pochodził z 1660 roku. Został konsekrowany przez biskupa kijowskiego (ale przebywającego na Warmii), Tomasza Ujejskiego, na cześć Najświętszej Maryi Panny. Miał napis: „Deum honoro, plebem convoco, defunctos deploro" (Boga czczę, lud zwołuję, zmarłych opłakuję). Ważył 45 centnarów. Drugi został odlany w 1727 roku i konsekrowany przez biskupa pomocniczego Jana Franciszka Kurdwanowskiego ${ }^{12}$, ku czci św. Jana Nepomucena. Trzeci został wykonany w 1786 roku na zamówienie prowizora (witrykusa) kościoła, Michała Skrzypskiego, i poświęcony ku czci Michała Archanioła. Czwarty, nazywany apostolskim, był poświęcony świętym apostołom Piotrowi i Pawłowi, a piąty - najmniejszy - konsekrowany 7 sierpnia 1714 roku ku czci Zwiastowania Pańskiego również przez biskupa Kurdwanowskiego ${ }^{13}$.

$\mathrm{Na}$ froncie kościoła, skierowanego na wschód, w 1731 roku została zbudowana wieżyczka, a w niej umieszczono sygnaturkę. Kruchta po stronie północnej miała dwoje drzwi: zewnętrzne i wewnętrzne z mocnym zamkiem. Po stronie zachodniej były drzwi dębowe, zamykane od wewnątrz drewnianym ryglem oraz mocnym zamkiem ${ }^{14}$.

Szczegółowo zinwentaryzowano ołtarze. Było ich wówczas 14. Główny został konsekrowany 5 sierpnia 1714 roku ku czci św. Jana Chrzciciela i św. Jana Ewangelisty przez biskupa Kurdwanowskiego. W protokole zaznaczono, że był pięknie rzeźbiony i pozłacany. Składał się z trzech kondygnacji. W pierwszej był obraz św. Jana Chrzciciela, udzielającego chrztu Chrystusowi. Po bokach znajdowało się 6 figur świętych: Jana Chrzciciela i Jana Ewangelisty, Piotra i Pawła, Andrzeja i Jakuba. W drugiej kondygnacji umieszczono obraz św. Elżbiety, patronki miasta, a po bokach figury świętych: Bartłomieja, Filipa, Tomasza i Mateusza. Ostatnią kondygnację zdobiła figura Matki Bożej Niepokalanej, a po bokach rzeźby św. Szymona i św. Judy. W zwieńczeniu - scena przedstawiająca Boga Ojca w otoczeniu Aniołów ${ }^{15}$.

Jako drugi wymieniono ołtarz św. Barbary. Usytuowany był po stronie Ewangelii. Składał się z murowanej mensy, miał nienaruszony portatyl i dwie kondygnacje. W pierwszej był wizerunek św. Barbary, a po bokach figury św. Jana Nepomucena i św. Mikołaja, w drugiej - obraz św. Wawrzyńca i po bokach figury św. Urszuli oraz św. Doroty, a w zwieńczeniu - gorejące Serce Jezusa ${ }^{16}$.

${ }^{12}$ Tamże, s. 180.

${ }^{13}$ Tamże, k. 16.

${ }^{14}$ Tamże, k. 16v.

${ }^{15}$ Tamże, k. 20 v. A. Boetticher, (Die Bau- und Kunstdenkmäler der Provinz Ostpreußen, cz. 4 : Das Ermland, Königsberg 1894, s. 274) podaje, że ołtarz został zbudowany w latach 1739-1746. Zapewne tę cezurę czasową należy skorygować, ponieważ bp Kurdwanowski zmarł w 1729 r., a zatem data konsekracji, wymieniona w protokole, wydaje się prawdziwą.

${ }^{16}$ Por. Boetticher, Die Bau- und Kunstdenkmäler, s. 275. 
Po stronie Lekcji był ołtarz św. Marcina - jak napisano - bardzo stary i ,słabej budowy". Planowano zastapić go nowym, na co 3 czerwca 1798 roku wyraził zgodę administrator diecezji, ks. kanonik Jan Nepomucen Cichowski ${ }^{17}$.

Po stronie północnej znajdowała się kaplica i ołtarz Najświętszej Maryi Panny. Konsekrował go 7 stycznia 1618 roku biskup warmiński, Szymon Rudnicki, dodatkowo ku czci św. Elżbiety, św. Doroty i św. Agnieszki. Przechowywano w nim relikwie św. Krystyny i 11000 męczenników. Na dole - przedstawienie cudu w Kanie Galilejskiej, w środku - figura Matki Bożej z Dzieciątkiem Jezus, a po bokach dwa skrzydła drewniane, ruchome, na których były ukazane tajemnice radosne z życia Matki Bożej oraz Chrystus - nauczający, ukrzyżowany i zdjęty z Krzyża ${ }^{18}$.

Ołtarz św. Józefa stał przy filarze naprzeciw ołtarza Matki Bożej. Konsekrował go biskup Jan F. Kurdwanowski 5 sierpnia 1714 roku (czyli razem z głównym). W środku ołtarza był obraz Matki Bożej i św. Józefa z Dzieciątkiem, nad nimi unosił się Duch Święty i Bóg Ojciec. Po bokach stały figury św. Walentego i św. Apolonii, a u samej góry - obraz Nawiedzenia Matki Bożej u św. Elżbiety.

Po stronie północnej zbudowano jeszcze kaplicę z ołtarzem św. Michała Archanioła i Aniołów Stróżów, który także został poświęcony przez biskupa Kurdwanowskiego 5 sierpnia 1714 roku. W środku znajdował się obraz św. Michała Archanioła, po bokach figury św. Franciszka z Asyżu i św. Jana Nepomucena, a u góry obraz św. Rocha.

Naprzeciwko ołtarza św. Michała Archanioła, przy filarze, stał ołtarz św. Kajetana z wizerunkiem tego świętego z rzeźbami dwóch Aniołów po bokach. Wyżej był obraz św. Walentego, a w zwieńczeniu w języku hebrajskim imię Elohim (jeden z tytułów Boga Jahwe) w glorii. Ołtarz był pomalowany na biało i pozłacany w 1796 roku $^{19}$.

Po stronie północnej znajdowała się także kaplica z ołtarzem Świętego Krzyża, z żelaznymi kratami. Dodatkowo ołtarz był poświęcony św. Andrzejowi i św. Bartłomiejowi. Konsekrował go - podobnie jak ołtarz NMP - 7 stycznia 1618 roku biskup warmiński, Szymon Rudnicki. W środku umieszczono wizerunek Chrystusa Ukrzyżowanego, a wyżej Chrystusa ukazującego swoje rany.

Po przeciwnej stronie, czyli południowej, była kaplica z ołtarzem św. Anny, konsekrowanym 7 stycznia 1618 roku (tu nadmieniono, że w święto Objawienia Pańskiego) również przez biskupa S. Rudnickiego. W środku ołtarz posiadał obraz Świętej Rodziny, wyżej św. Katarzyny i w trzeciej kondygnacji - Trzech Króli. Po bokach stały figury św. Sebastiana i św. Wojciecha ${ }^{20}$. W kaplicy gromadziły się na modlitwę siostry zakonne (katarzynki) ${ }^{21}$.

\footnotetext{
${ }^{17}$ Kopiczko, Duchowieństwo katolickie, s. 45.

${ }^{18}$ AAWO, AB, sygn. B 47, k. 20v-21.

${ }^{19}$ A. Boetticher, Die Bau- und Kunstdenkmäler, s. 279.

${ }^{20}$ Tamże.

${ }^{21}$ AAWO, AB, sygn. B 47, k. 21-21v.
} 
W dalszej kolejności wymieniono kaplicę i ołtarz świętych Apostołów Piotra i Pawła, konsekrowane przez biskupa pomocniczego Jana F. Kurdwanowskiego, czyli musiało to mieć miejsce między 1713 i 1729 rokiem. ${ }^{22} \mathrm{~W}$ pierwszej kondygnacji umieszczono obraz Chrystusa przekazującego klucze św. Piotrowi w otoczeniu pozostałych Apostołów. Zamiast kolumn były ruchome skrzydła z namalowanymi tajemnicami Męki Pańskiej oraz św. Piotra idącego po wodzie i jego męczeństwo, a także nawrócenie Szawła i jego męczeństwo. W górnej części była figura Matki Bożej z Dzieciątkiem Jezus, a na szczycie - Chrystusa Zmartwychwstałego ${ }^{23}$.

Przy filarze naprzeciw ołtarza świętych Apostołów Piotra i Pawła stał ołtarz ku czci Matki Boskiej Różańcowej, św. Dominika i Katarzyny Sieneńskiej, konsekrowany 5 sierpnia 1714 roku przez biskupa J. Kurdwanowskiego. Na środku był obraz Matki Bożej w srebrnej, częściowo pozłacanej sukni, a po bokach figury św. Dominika i św. Teresy. W drugiej kondygnacji umieszczono wizerunek Matki Bożej z Dzieciątkiem Jezus, natomiast wokół ołtarza wisiało 15 plastycznych przedstawień tajemnic różańcowych ${ }^{24}$.

Po stronie południowej była też kaplica z ołtarzem pw. św. Marii Magdaleny oraz św. Jakuba Młodszego i św. Macieja, konsekrowana przez biskupa S. Rudnickiego 7 stycznia 1618 roku. Wizerunek świętej znajdował się w środku, po bokach zaś - dwa ruchome skrzydła: na zewnętrznej stronie z obrazami świętych: Łazarza, Heleny, Maksyma i Marty, a na wewnętrznej: wskrzeszenia św. Łazarza, świętych Marty i Magdaleny z Chrystusem, św. Magdaleny przy grobie Chrystusa i ukazania się Chrystusa św. Magdalenie, a w górnej części wizerunek Ukrzyżowanego z figurami obok: Matki Bożej, św. Jana, św. Marii Magdaleny, św. Jakuba Starszego i św. Macieja ${ }^{25}$.

Przy filarze, naprzeciw ołtarza św. Marii Magdaleny, umieszczony był ołtarz św. Antoniego Padewskiego, konsekrowany przez biskupa J.F. Kurdwanowskiego 5 sierpnia 1714 roku i poświęcony na cześć świętych: Jakuba, Macieja, Krzysztofa, Antoniego opata i Barbary. Dodano w tym miejscu, że był on niedawno zbudowany (może odnowiony) i „piękną robotą przyozdobiony”. W środku znajdował się obraz św. Antoniego z Padwy - jak podaje Adolf Boetticher namalowany w 1792 roku przez Langhankiego z Bisztynka ${ }^{26}$. Po bokach były figury dwóch Apostołów: Jakuba i Macieja, w górnej kondygnacji - obraz św. Jana Nepomucena, a w zwieńczeniu wypisane złotymi literami imię Jehowa.

Jako ostatnią wymieniono kaplicę i ołtarz pw. Trójcy Przenajświętszej, Zwiastowania Pańskiego NMP, św. Wojciecha i św. Jerzego, też konsekrowany 5 sierpnia 1714 roku przez biskupa J. Kurdwanowskiego. Pośrodku, między

${ }^{22}$ Zapewne jednak chodzi o 5 sierpnia 1714 r., czyli dzień konsekracji innych ołtarzy przez biskupa pomocniczego J.F. Kurdwanowskiego.

${ }^{23}$ Tamże, k. 21v; Boetticher, Die Bau- und Kunstdenkmäler, s. 276.

${ }^{24}$ Por. Boetticher, Die Bau- und Kunstdenkmäler, s. 280.

${ }^{25}$ AAWO, AB, sygn. B 47, k. 21v. Por. Boetticher, Die Bau- und Kunstdenkmäler, s. 279.

${ }^{26}$ Boetticher, Die Bau- und Kunstdenkmäler, s. 280. 
dwoma filarami, umieszczono obraz Zwiastowania Pańskiego, po bokach figury św. Michała i św. Wojciecha, a w górnej części wizerunek Ukoronowania Najświętszej Maryi Panny przez Boga Ojca i Syna Bożego ${ }^{27}$.

$\mathrm{W}$ opisach ołtarzy podawano jeszcze informacje o mensach, dodatkowych zdobieniach i umieszczonych w nich relikwiach, które pominęliśmy w niniejszym tekście ze względu na ich szczegółowe opisy. Wszystkie były wyposażone w krzyże, lichtarze, a każdy przykryty trzema obrusami. Może warto jeszcze dodać, że w protokole odnotowano dwa tabernakula. Jedno - duże - służyło do przechowywania monstrancji z Najświętszym Sakramentem, rzeźbione, wyłożone materiałem jedwabnym, wyhaftowanym złotymi nićmi przez ,już zmarłą szlachetną pannę de Mathy". Drugie - małe - wykonane z drewna, pięknie zdobione, też wyłożone materiałem wyhaftowanym przez pannę de Mathy (m.in. kłos pszenicy i gałązka winnej latorośli) ${ }^{28}$.

W kościele stało sześć konfesjonałów: dwa obok ołtarza głównego, trzeci przy drzwiach wejścia północnego, czwarty w kaplicy św. Michała Archanioła, piąty w kaplicy Świętego Krzyża, a szósty w kaplicy Trójcy Przenajświętszej.

Chrzcielnica, wstawiona po stronie północnej w kaplicy św. Michała Archanioła, była wykonana $\mathrm{z}$ drewna lipowego i rzeźbiona. W dolnej części miała 4 kolumny z widocznymi rzeźbami, wyżej - figura św. Jana Chrzciciela z 1797 roku. We wnętrzu znajdował się kociołek cynowy z pokrywką na wodę chrzcielną. Zamykana była dwoma drzwiczkami, a klucz do nich przechowywano w zakrystii ${ }^{29}$.

Zakrystia, ze sklepieniami z cegły, miała trzy okna z żelaznymi kratami oraz drzwi dębowe z żelaznym okuciem i dobrym zamkiem. Znajdowały się w niej dwie szafy przy ścianach, jedna zwrócona na wschód, a druga na zachód z wieloma szufladami do przechowania szat i paramentów kościelnych. Były też dwie szafy usytuowane we wnękach muru, w tym jedna na cenne przedmioty, zamykana dwoma żelaznymi sztabami. Stał też klęcznik z tablicami modlitw odmawianych przez kapłanów przed Mszą św. i po jej odprawieniu, księgi liturgiczne i umywalka z ręcznikiem dla kapłanów. W kościele były dwie krypty, ale korzystanie z nich zostało zabronione przez władze pruskie ${ }^{30}$.

Dużo uwagi poświęcono uposażeniu kościoła oraz wyposażeniu w paramenty liturgiczne i szaty, ale te informacje także pominiemy w tym opracowaniu.

W sprawozdaniu odnotowano porządek odprawiania nabożeństw. W niedziele i święta o godz. 6.00 dzwoniono sygnaturką, a o 6.30 wielkim dzwonem na jutrznię. Liturgię rozpoczynał archiprezbiter lub inny, wyznaczony duchowny, a w śpiewy włączał się nauczyciel z uczniami. Po czytaniu była homilia, a następnie dalsza część Liturgii. Potem kapłan mający kazanie celebrował Mszę św. O godz. 8.00 - dla wygody ludu - odprawiano drugą Mszę św. recytowaną. Kwadrans przed godz. 9.30 było kazanie, zapowiadane dużym dzwonem i poprzedzone śpiewem pieśni w zależności od okresu liturgicznego. Po kazaniu nauczyciel

\footnotetext{
${ }^{27}$ AAWO, AB, sygn. B 47, k. 21v-22; Boetticher, Die Bau- und Kunstdenkmäler, s. 279.

${ }^{28}$ AAWO, AB, sygn. B 47, k. 19.

${ }^{29}$ Tamże, k. 19v; Boetticher, Die Bau- und Kunstdenkmäler, s. 281.

${ }^{30}$ AAWO, AB, sygn. B 47, k. 22.
} 
intonował kolejną pieśń, potem była aspersja (w niektóre święta także procesja z Najświętszym Sakramentem) i Msza św. główna (suma); po niej Anioł Pański. Po południu o godz. 14.00 dużym dzwonem dawano znak na śpiewanie różańca i nieszporów pod kierunkiem nauczyciela z uczniami (zazwyczaj na dwa chóry). W dni powszednie Msze św. były o godz. 6.00 i 8.00 recytowane lub śpiewane.

$\mathrm{Na}$ nieszpory wyznaczano godz. 15.00 , z wyjątkiem wielkiego postu, kiedy śpiewano je przed południem, a po południu - nabożeństwo okresowe. Przez cały adwent odprawiano przy głównym ołtarzu o godz. 6.30 Mszę św. roratnią. Na Anioł Pański dzwoniono trzy razy dziennie o 6.00, w południe i o 18.00 .

W każdy piątek dużym dzwonem dawano znak na rozważanie Męki Pańskiej. W celu zyskania odpustów należało odmówić „Ojcze nasz” i „Zdrowaś Maryjo” według polecenia Benedykta XIV (papież w latach 1740-1758) ${ }^{31}$.

Dla większej chwały Bożej i czci świętych przy kościele archiprezbiterialnym w Ornecie działało kilka bractw. Jedno z nich nosiło nazwę Świętej Rodziny i zostało założone 20 maja 1729 roku. ${ }^{32}$ Drugie, pw. Różańca św., zostało powołane po staraniach ks. archiprezbitera orneckiego Kaspra Simonisa i ks. proboszcza z Lechowa, Jana Gehrmana, przez magistra generalnego dominikanów, Tomasza Ripolla, 21 listopada 1706 roku. ${ }^{33}$

Za najstarsze można uważać bractwo Bożego Ciała, erygowane 1 listopada 1379 roku przez Henryka III Sorboma, któremu papież Paweł V na mocy brewe apostolskiego z 5 kwietnia 1611 roku nadał specjalne odpusty ${ }^{34}$. 28 marca 1516 roku biskup warmiński, Fabian Luzjański - na prośbę mieszkańców Ornety - odnowił bractwo Najświętszej Maryi Panny, które istniało wcześniej, ale zostało zaniedbane ${ }^{35}$. Działało też bractwo św. Marii Magdaleny, które erygował 9 kwietnia 1585 roku biskup warmiński, Marcin $\mathrm{Kromer}^{36}$. Było również bractwo św. Jakuba, które założył były wikariusz ornecki ks. Jerzy Schwanbach ${ }^{37}$, a zatwierdził 10 stycznia 1537 roku biskup Maurycy Ferber ${ }^{38}$. Jako siódme zostało wymienione bractwo Kapłanów, powołane w 1491 roku przez biskupa Łukasza Watzenrodego, ale - jak odnotowano - już od wielu lat zaniedbane ${ }^{39}$.

${ }^{31}$ Tamże, k. 22v

${ }^{32}$ Tamże, k. 23; G. Matern, Die kirchlichen Bruderschaften in der Diözese Ermland, Braunsberg 1920, s. 79.

${ }^{33}$ AAWO, AB, sygn. B 47, k. 23; Matern, Die kirchlichen Bruderschaften, s. 70.

${ }^{34}$ Por. Matern, Die kirchlichen Bruderschaften, s. 162-165; CDW III, s. 56 (nr 83).

${ }^{35}$ Matern, Die kirchlichen Bruderschaften (s. 55-56), podaje, że pierwotnie zostało erygowane 11 kwietnia $1442 \mathrm{r}$.

${ }^{36}$ Por. Matern, Die kirchlichen Bruderschaften, s. 101. Wcześniej takie bractwo istniało już w Bartoszycach i to od 1484 r. Wcześniej istniało bractwo ubogich, które zostało zastąpione przez bractwo św. Marii Magdaleny. Tamże, s. 175.

37 Zob. A. Kopiczko, Katalog duchowieństwa katolickiego $w$ diecezji warmińskiej (do 1945 roku), Olsztyn 2003, s. 99.

${ }^{38}$ Por. Matern, Die kirchlichen Bruderschaften, s. 92-93.

${ }^{39}$ AAWO, AB, sygn. B 47, k. 23; Matern, Die kirchlichen Bruderschaften, s. 101 (pierwotnie powołane już za biskupa Henryka III Sorboma, czyli między 1373 a 1401 r.). 
Przy kościele istniał cmentarz na placu przykościelnym, otoczony od strony północnej i wschodniej murem, a od południowej i zachodniej budynkami wikarówki i szkoły, murem miejskim i plebanią. Miał pięć bram, z których jedna, większa, była skierowana $\mathrm{w}$ stronę frontonu kościoła i służyła do wnoszenia zmarłych, dwie inne były usytuowane od strony wschodniej i te otwierano dla wiernych. Jednak odnotowano, że cmentarz był już za mały i grzebano na nim tylko mieszczan, a ze wsi parafialnych osadników oraz ich żony i dzieci. Pozostali mieli swoje groby na dwóch innych cmentarzach usytuowanych - jeden w kierunku Krosna, a drugi - Krzykał. Oba były otoczone parkanem i zamykane, by na ich teren nie wchodziły zwierzęta ${ }^{40}$.

$\mathrm{W}$ dalszej kolejności $\mathrm{z}$ dokumentu powizytacyjnego dowiadujemy się o wiernych, duszpasterzach i pracownikach kościelnych. Parafian zobowiązanych do przyjmowania Komunii św. wielkanocnej, którzy zadośćuczynili temu obowiązkowi, odnotowano 2500 (czyli bez dzieci przed I Komunią św.). Ponadto przystępowali do niej katolicy z Prus (mieszkający między protestantami) w liczbie do $400^{41}$. Natomiast na terenie parafii mieszkało 60 luteranów, którzy odprawiali swoje nabożeństwa w gmachu magistratu, ponieważ nie mieli własnej świątyni ${ }^{42}$.

Proboszczem parafii (i zarazem archiprezbiterem) był ks. Tomasz Orlikowski, Pomorzanin, urodzony 21 grudnia 1755 roku. Święcenia kapłańskie otrzymał na mocy dymisorii ${ }^{43}$ biskupa włocławskiego, Józefa Rybińskiego, po otrzymaniu prowizji do kościoła orneckiego, 8 listopada 1780 roku z rąk biskupa pomocniczego warmińskiego, Karola de Zehmena. 30 kwietnia 1785 roku został mianowany przez biskupa warmińskiego, Ignacego Krasickiego, tutejszym archiprezbiterem. Znał języki: łaciński, niemiecki i polski ${ }^{44}$.

W posłudze duszpasterskiej wspierało go trzech wikariuszy. Pierwszy z nich, ks. Antoni Rehan, urodził się 16 czerwca 1758 roku we Fromborku ${ }^{45}$. Święcenia kapłańskie otrzymał w 1781 roku z rąk biskupa pomocniczego warmińskiego, Karola de Zehmena, wcześniej otrzymując prowizję od archiprezbitera orneckiego, ks. kanonika Teodora Lutomskiego. W 1804 roku został komendariuszem parafii w Bisztynku, a od 1810 roku tamtejszym proboszczem. Zmarł 4 czerwca $1821 \mathrm{roku}^{46}$.

${ }^{40}$ AAWO, AB, sygn. B 47, k. 23.

${ }^{41}$ Tamże, k. 24.

${ }^{42}$ Tamże, k. 24, 29.

43 Dymisorie to pisma przełożonego kościelnego, zezwalające klerykowi na przyjęcie święceń diakonatu lub kapłaństwa. P. Hemperek, Dymisorie, w: Encyklopedia Katolicka, t. 4, red. R. Łukaszczyk, L. Bieńkowski, F. Gryglewicz, Lublin 1985, kol. 419-420.

${ }^{44}$ Należy dodać, że w 1808 r. został kanonikiem warmińskim, a w latach 1815-1820 był wikariuszem generalnym diecezji. Zmarł 21 grudnia 1824 r. we Fromborku. Kopiczko, Duchowieństwo katolickie, s. 237.

${ }^{45}$ AAWO, Frombork, Księga chrztów (E 169). Jego ojcem był burgrabia Fromborka, Antoni Rehan, a matką Katarzyna z d. Mocka.

${ }^{46}$ AAWO, AB, sygn. B 47, k. 30; Kopiczko, Duchowieństwo katolickie, s. 264. 
Drugim kapłanem pomocniczym był ks. Franciszek Wegner, urodzony 16 września 1761 roku w Lidzbarku Warmińskim. Jego rodzicami byli Franciszek i Elżbieta. Ukończył Seminarium Papieskie w Braniewie i 24 września 1784 roku otrzymał święcenia kapłańskie z rąk biskupa warmińskiego, I. Krasickiego, z prowizją do kościoła w Osetniku. 19 września 1788 roku został przeniesiony do kościoła w Ornecie. Znał języki łaciński i niemiecki. W 1804 roku został proboszczem w Wilczkowie. Tam zmarł 27 stycznia $1808 \mathrm{roku}^{47}$.

Trzecim kapłanem pomocniczym, nazywanym właściwym wikariuszem, był ks. Jan Kolberg, urodzony 30 stycznia 1768 roku w Tolkmicku. Święcenia kapłańskie otrzymał z prowizją do kościoła w Płoskini 29 maja 1791 roku z rąk biskupa pomocniczego K. de Zehmena. 24 lipca 1793 roku został przeniesiony na wikariat do Ornety. Znał języki łaciński i niemiecki. W 1806 roku został proboszczem w Ełdytach Wielkich, w roku następnym w Krośnie, a w 1820 roku kapelanem w szpitalu św. Anny we Fromborku. Tam zmarł 3 marca 1832 roku.

Duszpasterze pomocniczy wspierali archiprezbitera w pracy duszpasterskiej. Obowiązki te wypełniali - w świetle opinii wizytatora - sumiennie i gorliwie. Pewne problemy odnotowano jedynie z ks. J. Kolbergiem, dlatego też został upomniany ${ }^{48}$.

Obowiązkiem wizytatora było też sprawdzenie stanu szkoły. Niestety, w 1798 roku budynek określono jako zniszczony i nienadający się do użytku. Tymczasowo - do wybudowania nowego - miasto przekazało dom, położony poza obrębem placu kościelnego. Czyniono jednak starania o własny obiekt i w tej sprawie nawiązano współpracę z architektem prowincji pruskiej, Ernstem Masuhrem. Przybył on także do Ornety w czasie wizytacji, by w tej sprawie rozmawiać $\mathrm{z}$ wizytatorem oraz archiprezbiterem. Zakładano, że prace ruszą już na wiosnę przyszłego roku (czyli 1799 roku) ${ }^{49}$.

Funkcję kierownika i nauczyciela w szkole sprawował Franciszek Eckert, liczący wówczas 60 lat i żonaty. Wcześniej przez trzy lata pracował on jako kantor, a obowiązki w szkole przejął 1 maja 1794 roku. Wypełniał je bardzo pilnie i to zarówno w szkole, jak i w kościele (jako organista). Wspierał go syn Andrzej, który był kantorem. Miał 26 lat i też przejął te obowiązki 1 maja 1794 roku. ${ }^{50}$ Ten otrzymywał jako wynagrodzenie od kierownika szkoły rocznie 13 imperiałów i 30 groszy. Do tego dochodziło 10 imperiałów z beneficjum oraz 1/3 dochodów nauczyciela $\mathrm{z}$ pogrzebów. Jako muzyk w kościele orneckim miał dodatkowo 8 imperiałów i 30 groszy, a z kasy miasta 12 imperiałów ${ }^{51}$.

$\mathrm{W}$ Ornecie pojawiły się jednak problemy z wynagrodzeniem kierownika szkoły. Część rodzin nie uiszczała wyznaczonych opłat, postanowiono zatem, że nad ściąganiem należności będzie czuwać rada miasta ${ }^{52}$. W dalszej części podano, że od każdego ucznia nauczyciel otrzymywał kwartalnie 10 groszy

\footnotetext{
${ }^{47}$ AAWO, AB, sygn. B 47, k. 30; Kopiczko, Duchowieństwo katolickie, s. 342.

${ }^{48}$ Tamże; tamże, s. 157.

${ }^{49}$ AAWO, AB, sygn. B 47, k. 13v.

${ }^{50}$ Tamże, k. 39v; F. Buchholz, Bilder aus Wormditts Vergangenheit, Wormditt 1931, s. 62.

${ }^{51}$ Tamże, k. 44v.

${ }^{52}$ AAWO, AB, sygn. B 47, k. 14.
} 
na drewno do ogrzewania szkoły oraz rocznie po 18 groszy na utrzymanie. $\mathrm{Na}$ świętego Marcina nauczyciel odwiedzał mieszkańców miasta i przy tej okazji zbierał ok. 4 imperiały i 60 groszy, a na świętego Grzegorza 1 imperiał. Za udział w pogrzebach roczne dochody wynosiły ok. 33 imperiały i 30 groszy. Obywatele i mieszkańcy miasta oraz osadnicy i mieszkańcy wsi (należących do parafii oprócz Opina) byli zobowiązani płacić rocznie po 6 groszy, ale - jak podano wyżej - nie wszyscy wywiązywali się z tego obowiązku. $Z$ tych opłat nauczyciel otrzymywał rocznie ok. 25 imperiałów, 56 groszy i 6 denarów. Dodatkowo korzystał z trzech beneficjów: Litanii, Któryś za nas cierpiat i Niechaj będzie pochwalony. Pierwsze założył młynarz ornecki Marcin Miltzstrey i przeznaczył sumę kapitałową 61 imperiałów i 10 groszy. Fundatorem drugiego był kanonik warmiński, Jerzy Marquardt (33 imperiałów i 30 groszy) ${ }^{53}$, a trzeciego ks. Andrzej Peltz (fundacja z 24 października 1700 roku, kapitał też 33 imperiały i 30 groszy) $)^{54}$.

W szkole parafialnej w Ornecie uczyło się 90 chłopców. Wykorzystywano różne podręczniki, w tym dla sylabizujących i czytających, katechizm ks. kanonika Schmidta $^{55}$ (wydany w Królewcu) oraz podręczniki do łaciny Donata i jezuity Alvarusa. Wielu chłopców uczyło się także arytmetyki, a wszyscy - oprócz sylabizujących - pisali i ,posiadali dobre obeznanie” w języku łacińskim ${ }^{56}$.

Na przedmieściach Ornety działała też druga szkoła, w której uczył od trzech lat Jan Gehrmann, żonaty i rzetelnie wypełniający obowiązki ${ }^{57}$. Wspomniano również szkołę prowadzoną przez siostry katarzynki, w której 86 dziewcząt uczyło się czytania, pisania, prawd wiary oraz robótek ręcznych. Na ten cel wydzielono w klasztorze dużą salę. Jako wynagrodzenie zakonnice pobierały od każdej uczennicy 2 grosze ${ }^{58}$.

Organistą w kościele orneckim był Antoni Krohnenberger. Miał 34 lata, był żonaty i znał języki polski oraz niemiecki. Przez trzy lata pracował w kościele parafialnym we Wrzesinie. Do pracy w Ornecie został przyjęty w 1792 roku. Obowiązki wypełniał rzetelnie, a jako wynagrodzenie otrzymywał z kasy

${ }^{53}$ Ur. w 1591 r. w Ornecie. W 1619 r. przyjął święcenia kapłańskie. Był proboszczem w Rydze, potem w Lidzbarku Warmińskim. Kanonikiem fromborskim został w 1630 r. Cieszył się względami biskupów warmińskich i królów Polski. Zm. w 1660 r. Kopiczko, Duchowieństwo katolickie, s. 211.

${ }^{54}$ Ur. w 1653 r. w Opinie. Święcenia kapłańskie przyjął w 1680 r. Potem pracował jako wikariusz w Biskupcu, Henrykowie i Lubominie. W 1701 r. ustanowiony wikariuszem w Ornecie, a w 1711 r. kaznodzieją w Krośnie. Tam zmarł w 1731 r. Tamże, s. 242; AAWO, AB, sygn. B 47, k. 44-44v.

${ }^{55}$ Zapewne chodzi o kanonika Franciszka Ksawerego Schmidta, ur. w 1739 r. w Reszlu, który w latach 1780-1786 był proboszczem w Królewcu, a następnie doktorem teologii w Wilnie. Był kanonikiem dobromiejskim. Zmarł w 1801 r. w Dobrym Mieście. Kopiczko, Duchowieństwo katolickie, s. 285-286.

${ }^{56}$ AAWO, AB, sygn. B 47, k. 45.

${ }^{57}$ Tamże.

${ }^{58}$ Tamże, k. 14, 45. 
parafialnej 40 imperiałów oraz z kasy miejskiej 26 imperiałów i 60 groszy. Do tego dochodziły pieniądze z beneficjów - 16 imperiałów, 80 groszy i 15 denarów, od Mszy św. pogrzebowych - ok. 6 imperiałów i 60 groszy oraz za lekcje muzyki ok. 20 imperiałów ${ }^{59}$.

Jako kościelny pracował Jan Koless, urodzony we Fromborku. Miał 50 lat ${ }^{60}$. Funkcję objął w 1790 roku. W obowiązkach był pilny i czujny, choć zdarzało się, że nadużył alkoholu. Jako wynagrodzenie otrzymywał z kasy kościelnej 20 imperiałów i 10 groszy, z beneficjów 18 imperiałów, 73 grosze i 6 denarów, z kolędy w mieście - ok. 6 imperiałów i 60 groszy, z kolędy na wsiach od archiprezbitera $1 / 3$, od każdego zawartego małżeństwa po 6 groszy, tak samo od każdego chrztu i po 3 grosze od każdego wywodu. Jego dom - podobnie jak szkoła - był w ruinie. Ponieważ mieszczanie byli bardzo biedni i nie posiadali środków na wybudowanie nowego budynku (mieli taki obowiązek), magistrat ornecki poprosił Kurię Biskupią, by wyraziła zgodę na sprzedaż domu kościelnego oraz by uzyskane pieniądze przeznaczyć na nową szkołę. Za to zobowiązywał się przygotować mieszkania dla nauczyciela, kantora i kościelnego. Odpowiedź była pozytywna, a kościelny miał otrzymać lokum w nowym budynku szkolnym ${ }^{61}$.

Spośród pracowników kościelnych wymieniono jeszcze grabarza, który pełnił także obowiązki kalikanta. Był nim Jakub Braun, urodzony w Ornecie, lat 48, żonaty, a pracował już od 12 lat. Tytułem wynagrodzenia otrzymywał z kasy kościelnej 3 imperiały i 80 groszy, z beneficjów 8 imperiałów, od pogrzebów za kopanie grobów rocznie 66 imperiałów i 60 groszy, od przygotowania grobu $\mathrm{w}$ zimie dla dorosłego - 1 imperiał, a w lecie - 60 groszy, natomiast dla dziecka odpowiednio - 45 i 30 groszy. Ponadto miał pokój w budynku parafialnym ${ }^{62}$.

Dodatkowo w parafii były dwie zaprzysiężone akuszerki, w tym jedna po ukończonej szkole. Zarówno one, jak i inne niewiasty, które zajmowały się tą posługą, były dobrze przygotowane do udzielenia chrztu w przypadku nagłej potrzeby ${ }^{63}$.

27 września wizytator odwiedził też obydwa szpitale: Ducha Świętego (znajdujący się w obrębie murów miasta) i św. Jerzego (na przedmieściu). Przy tej okazji napisał, że pierwszy został uposażony przez biskupa Jana Stryprocka (1355-1373) sześcioma łanami ziemi, co zostało potwierdzone w odnowionym przywileju lokacyjnym z 14 sierpnia 1359 roku$^{64}$. Ponadto Henryk Molknecht

${ }^{59}$ Tamże, k. 45v.

${ }^{60} \mathrm{~W}$ księdze chrztów z Fromborka występuje Jan Kolles, syn rybaka Adalberta i Katarzyny, urodzony 12 lutego 1746 r. - AAWO, Frombork, księga chrztów, sygn. E 169, k. 151v.

${ }^{61}$ AAWO, AB, sygn. B 47, k. 45v.

${ }^{62}$ Tamże.

${ }^{63}$ Tamże, k. 43v.

${ }^{64}$ Codex Diplomaticus Warmiensis oder Regesten und Urkunden zur Geschichte Ermlands, t. 2: Urkunden der Jahre 1341-1375 nebst Nachträgen von 1240-1340, wyd. C.P. Woelky, J.M. Saage, Mainz 1864, s. 288 (nr 288). 
z Ornety i jego żona podarowali 16 października 1384 roku - za potwierdzeniem biskupa Henryka III Sorboma - las o powierzchni sześciu łanów, z którego trzy łany przeznaczono dla szpitala Ducha Świętego i tyle samo dla szpitala św. Jerzego ${ }^{65}$.

W 1712 roku ustalono też, że do szpitala powinno się przyjmować tylko zasłużonych mieszkańców Ornety (mężczyzn i kobiety), w liczbie do dwunastu osób. W czasie wizytacji w 1798 roku przebywało w nim jedenaście osób, w tym dziewięć kobiet i dwóch mężczyzn - i jak zaznaczył wizytator - „nie z braku fundacji, lecz osób, które by się o nią bardzo starały"66.

Archiprezbiter ornecki przedstawił też rachunki, z których wynikało, że fundusze szpitala w ostatnim okresie znacząco wzrosły, tak że siedmiu starszych pacjentów otrzymywało tygodniową zapomogę w wysokości 10 groszy tygodniowo, a młodszych pięciu (w czasie wizytacji tych było czterech) po 5 groszy, ponadto 5 groszy, które pozostawały (z braku jednego pensjonariusza), dzielono między młodszych. Przyjęto też takie rozwiązanie, że młodsi byli przesuwani do grupy starszych po zwolnieniu miejsca. Archiprezbiter zaznaczył, że wystarczyłoby pieniędzy, by każdemu wypłacać po 10 groszy. W związku z tym wizytator tę propozycję zaakceptował i polecił wypłacanie każdemu pensjonariuszowi od 1 stycznia 1799 roku po 10 groszy tygodniowo ${ }^{67}$. Ponadto szpitalnicy otrzymywali na zakup jarzyn, słoniny i śledzi rocznie 25 imperiałów i 60 groszy do podziału oraz 4 korce żyta, 2 korce jęczmienia i 3 korce grochu. $Z$ lasu szpitalnego przeznaczano na opał 10 sążni drewna ${ }^{68}$.

Oprócz 6 łanów ziemi i 3 łanów lasu szpital posiadał jeszcze ogród przy drodze w kierunku Lidzbarka obok cmentarza, który w czasie wizytacji już użytkowali protestanci za zgodą rządu pruskiego z 10 września 1779 roku, płacąc za ten cmentarz 40 groszy tytułem rocznego czynszu ${ }^{69}$.

Wspomnianych 6 łanów ziemi specjalna komisja postanowiła w 1727 roku wydzierżawić „uczciwym i zasłużonym dla miasta obywatelom” na trzy lata, a po upływie tego czasu kontrakt mógł być odnowiony. W czasie wizytacji dzierżawcami byli: jednego łanu burmistrz Andrzej Wesler, drugiego rajca miejski Kazimierz Lighton, trzeciego prowizor kościoła Józef Wax, czwartego obywatel Franciszek Kobwald, piątego wdowa Anna Plastwich, a szóstego też wdowa Anna Hohsmann. Każdy z nich płacił za dzierżawę rocznie 6 imperiałów i 60 groszy. Ponadto byli zobowiązani do dostarczania drewna do obu szpitali ${ }^{70}$.

${ }^{65}$ Taka data widnieje w protokole, natomiast zatwierdzenie tej fundacji przez bpa Henryka Sorboma nastąpiło 21 października 1384 r. CDW III, s. 135-136 (nr 173; tu nazwisko zapisano jako Müllknecht i wspomniano o synu fundatora, Jakubie). W tym dokumencie jest jeszcze mowa o wyznaczeniu na rzecz szpitala ławy do sprzedaży mięsa w Ornecie; G. Matern, Die Hospitäler im Ermland, „Zeitschrift für die Geschichte und Altertumskunde Ermlands”, 16 (1905) s. 152;

A. Kopiczko, Ustrój i organizacja diecezji warmińskiej w latach 1525-1772, s. 223.

${ }^{66}$ AAWO, AB, sygn. B 47, k. 46

${ }^{67}$ Tamże, k. 14, 46.

${ }^{68}$ Tamże, k. 46.

${ }^{69}$ Tamże.

${ }^{70}$ Tamże. 
W 1754 roku administrator diecezji, kanonik Mikołaj Antoni Szulc, potwierdził, że szpital Ducha Świętego posiadał kapitał w wysokości 2007 imperiałów i 7 groszy. Do 1796 roku kapitał ten powiększył się o dochody z czynszów w wysokości 578 imperiałów i 23 groszy, czyli łącznie było to już 2585 imperiałów i 30 groszy. Suma ta była ulokowana na różnych dobrach i domach, wymienionych przez wizytatora. Największe sumy były zabezpieczone u Heykinga na dobrach nazywanych Bogatyńskie (zapis z 1 maja 1775 roku - 357 imperiałów i 30 groszy, drugi z 17 sierpnia 1786 roku - 667 imperiałów i 80 groszy oraz z 1789 roku - 83 imperiały i 30 groszy), u wdowy Tettau w Bemowiznie k. Braniewa (zapis z 24 marca 1796 roku - 558 imperiałów i 10 groszy), prowincjalnej kasie kredytowej w Morągu (24 grudnia 1793 roku - 561 imperiałów i 50 groszy i z 1798 roku - 107 imperiałów i 10 groszy). Znacznie mniejsze sumy (od 5 do 33 imperiałów) ulokowano w domach i ziemi mieszkańców Ornety ${ }^{71}$.

Dodano też, że budynek szpitala został wzniesiony z muru pruskiego. Miał dużą salę oraz 15 wydzielonych izb (komór) dla szpitalników. Prawo patronatu należało do rady miejskiej, która też mianowała prowizora, ale za wiedzą archiprezbitera. W czasie wizytacji funkcję tę pełnił sekretarz miasta Andrzej Thater, do którego obowiązków należało zarządzanie dochodami placówki oraz przyjmowanie pacjentów ${ }^{72}$.

W czasie odwiedzin szpitala wizytator zachęcił pacjentów do pobożności, zgodności pomiędzy sobą, wdzięczności dla zmarłych fundatorów, wyrażonej $\mathrm{w}$ modlitwie, oraz do pomagania sobie wzajemnie w chorobie ${ }^{73}$.

Ze szpitala Ducha Świętego wizytator udał się do leprozorium św. Jerzego. Pochodziło ono z pierwszej połowy XIV wieku i początkowo było usytuowane przy drodze prowadzącej do Braniewa. Po pożarze w 1520 roku zostało odbudowane nad rzeką Drwęcą ${ }^{74}$. W protokole odnotował i przy tym szpitalu fundację Henryka Molknechta z 16 października 1384 roku w wysokości 3 łanów lasu, z którego pobierano dla niego rocznie 10 sążni drewna. Posiadał również ogród przylegający do rzeki Drwęcy. Na mocy przywileju biskupa Maurycego Ferbera z 25 lipca 1531 roku otrzymywał 3 korce żyta z młyna w Ornecie ${ }^{75}$.

Podobnie jak w przypadku szpitala Ducha Świętego, administrator diecezji, Mikołaj Antoni Szulc, w 1754 roku potwierdził kapitał leprozorium w wysokości 673 imperiałów i 30 groszy. Z nowych czynszów od tego czasu doszło jeszcze 315 imperiałów, tak że w czasie wizytacji kapitał wynosił 988 imperiałów i 30 groszy. Ulokowane one były również w większości na dobrach Heykinga w Bogatyńskiem - 231 imperiałów (lokata z 17 sierpnia 1786 roku), u wdowy Tettau w Bemowiznie k. Braniewa - 66 imperiałów i 60 groszy (lokata z 24 marca 1796 roku), w prowincjalnej kasie kredytowej w Morągu - 261 imperiałów i 70 groszy (lokata z 24 grudnia 1793 roku) oraz tamże dodatkowo 27 imperiałów

${ }^{71}$ Tamże, k. 46-46v.

${ }^{72}$ Tamże, k. 46v-47.

${ }^{73}$ Tamże, k. 14v.

${ }^{74}$ Kopiczko, Ustrój i organizacja diecezji warmińskiej w latach 1525-1772, s. 223; Matern, Die Hospitäler, s. 154.

${ }^{75}$ AAWO, AB, sygn. B 47, k. 47; Matern, Die Hospitäler, s. 155. 
i 70 gorszy ( 24 czerwca 1798 roku), w domu Jana Hotsteina w Ornecie-22 imperiały i 20 groszy (11 listopada 1758 roku) oraz w domu Jakuba Hohna z Ornety - 18 imperiałów i 80 groszy (21 stycznia 1782 roku). Do sumy 988 imperiałów i 30 groszy doszło jeszcze 110 imperiałów z zapisu z 24 czerwca 1798 roku w kasie kredytowej w Morągu, co dało ostateczną kwotę 1098 imperiałów i 30 groszy $^{76}$.

Leprozorium, podobnie jak szpital, zostało zbudowane z muru pruskiego i miało jedną salę oraz sześć izb sypialnych. Przebywające w nim osoby otrzymywały na swoje utrzymanie dodatkowo 2 korce żyta, 1 korzec grochu i 1 korzec jęczmienia, oprócz drewna. Do tego dodawano jeszcze słoninę, sól i jarzyny (równowartość 12 talarów 78 groszy). Odnotowano także inne jałmużny. Prowizorami tego szpitala byli Józef Wax i Andrzej Teichert z Ornety, którzy wspólnie z archiprezbiterem odpowiadali za przyjmowanie pacjentów. Natomiast dochodami administrował sekretarz miasta, Andrzej Thater ${ }^{77}$. Wizytator skierował do pensjonariuszy podobne słowa jak w szpitalu Ducha Świętego. Przede wszystkich zachęcał ich do cierpliwości w znoszeniu cierpień ${ }^{78}$.

Na temat plebanii odnotowano, że została zbudowana w 1792 roku i ma solidne mury. W południowej części znajdowało się mieszkanie archiprezbitera, które składało się z trzech pokoi z sypialnią i komórką. Z drugiej strony był mały pokój, dalej pokój z komórkami dla służby. Na piętrze z jednej strony był pokój letni, a z drugiej mieszkanie wikariusza z sypialnią i komórką. Obok plebanii stał piętrowy spichlerz ze stajnią na dole, zbudowany z muru pruskiego. Stodoła z zasiekami znajdowała się poza miastem, była zbudowana z drewna i wymagała naprawy. Do reparacji budynków parafialnych i wznoszenia nowych byli zobowiązani katolicy $\mathrm{z}$ miasta, a znajdujących się poza granicami Ornety - parafianie z wiosek ${ }^{79}$.

$\mathrm{W}$ protokole powizytacyjnym jest ponadto wiele informacji o beneficjach, uposażeniu, kaplicach i kościołach filialnych oraz siostrach katarzynkach. W tym opracowaniu je pomijamy, ponieważ uwzględnienie wszystkich wydłużyłoby artykuł przynajmniej dwukrotnie. Zatem materiały te mogą być przedmiotem odrębnego opracowania.

Podsumowując zebrane informacje, należy podkreślić ich nowość w stosunku do dotychczasowych opracowań. Po raz pierwszy została podana liczba parafian i mieszkających na tym terenie luteranów. Szczegółowo przedstawiono porządek nabożeństw w niedziele, święta i dni powszednie. Opisano wystrój wnętrza, zwłaszcza wyposażenie ołtarzy i kaplic. Wymieniono fundacje oraz inne źródła dochodów kościoła i duszpasterzy. Przedstawiono bractwa, szkoły i szpitale. Dowiadujemy się także o cmentarzach. Jest to zatem nieocenione źródło do poznania przeszłości kościoła i parafii w Ornecie pod koniec XVIII wieku ${ }^{80}$.

76 Tamże.

77 Tamże, k. 47v.

${ }^{78}$ Tamże, k. 14v.

79 Tamże, k. 45.

${ }^{80}$ Boetticher, Die Bau- und Kunstdenkmäler, s. 270-285. O współczesnym wyposażeniu kościoła zob. A. Kopiczko, Porta Domini. Kościoły jubileuszowe i sanktuaria Świętego Krzyża $w$ archidiecezji warmińskiej, Olsztyn 2002, s. 79-84. 


\section{BIBLIOGRAFIA}

\section{Źródla rękopiśmienne}

Archiwum Archidiecezji Warmińskiej w Olsztynie

Archiwum Biskupie, sygn. B 47;

Frombork, księga chrztów, sygn. E 169.

\section{Źródła drukowane}

Codex Diplomaticus Warmiensis oder Regesten und Urkunden zur Geschichte Ermlands, t. 2: Urkunden der Jahre 1341-1375 nebst Nachträgen von 1240-1340, wyd. C.P. Woelky, J.M. Saage, Mainz 1864.

Codex Diplomaticus Warmiensis oder Regesten und Urkunden zur Geschichte Ermlands, t. 3: Urkunden der Jahre 1376-1424 nebst Nachträgen, wyd. C.P. Woelky, BraunsbergLeipzig 1874.

Rocznik Diecezji Warmińskiej, Olsztyn 1985.

\section{Opracowania}

Boetticher Adolf, Die Bau- und Kunstdenkmäler der Provinz Ostpreußen, cz. 4: Das Ermland, Königsberg 1894.

Buchholz Franz, Aus sechs Jahrhunderten. Bilder aus Wormditts Vergangenheit, Braunsberg 1912.

Buchholz Franz, Bilder aus Wormditts Vergangenheit, Wormditt 1931.

Hemperek Piotr, Dymisorie, w: Encyklopedia Katolicka, t. 4, red. F. Grylewski, Lublin 1985, kol. 419-420.

Kopiczko Andrzej, Ustrój i organizacja diecezji warmińskiej w latach 1525-1772, Olsztyn 1993.

Kopiczko Andrzej, Duchowieństwo katolickie diecezji warmińskiej w latach 1525-1821, cz. 2, Olsztyn 2000.

Kopiczko Andrzej, Porta Domini. Kościoły jubileuszowe i sanktuaria Świętego Krzyża $w$ archidiecezji warmińskiej, Olsztyn 2002.

Kopiczko Andrzej, Katalog duchowieństwa katolickiego w diecezji warmińskiej (do 1945 roku), Olsztyn 2003.

Matern Georg, Die Hospitäler im Ermland, „Zeitschrift für die Geschichte und Altertumskunde Ermlands", 16 (1905) s. 73-157.

Matern Georg, Die kirchlichen Bruderschaften in der Diözese Ermland, Braunsberg 1920.

Rzempołuch Andrzej, Architektura kościoła farnego w Ornecie, „Kwartalnik Architektury i Urbanistyki”, 2 (1981) s. 89-101.

Schmauch Hans, Zur Geschichte der St. Johannispfarrkirche zu Wormditt. Zum 550jährigen Jubiläum herausgegeben, Wormditt 1929.

Ulewicz Andrzej, Dąbrowski Józef, Filigrany w zasobie Archiwum Państwowego w Olsztynie, Olsztyn 2018. 


\title{
THE PARISH AND CHURCH IN ORNETA ACCORDING TO THE VISITATION REPORT OF 1798
}

\begin{abstract}
Summary
The article is based on the extensive visitation report of the parish of Orneta of 1798, written in Latin. It includes information on the beginnings of the church and its equipment. It describes in detail the altars, chapels, baptismal font and sacristy. In addition, there is information on the service times and brotherhoods. Interesting data concern the structure of the population. 2500 people were obliged to receive Easter Holy Communion, but about 400 Catholics from Protestant Prussia also came to the local church. Moreover, about 60 Lutherans lived in the parish; their services were held in the town hall. The report also contains the basic biographical details about the priests: the parish priest, Rev. Tadeusz Orlikowski and three curates: Rev. Antoni Rehan, Rev. Franciszek Wegner and Rev. Jan Kolberg. The inspector checked how the school functioned, gave the names of the teacher (Franciszk Eckert) and the cantor (Andrzej Eckert), as well as the number of students (90 boys). In the town there was also a school ran by the Congregation of the Sisters of St Catherine Holy Virgin and Martyr, where 86 girls learnt to read and write; in addition, they were taught catechism and needlework. The document also mentions the following church employees: an organist (Antoni Krohnenberg), a sacristan (Jan Koless), a gravedigger (Jakub Braun) and midwives. Moreover, there is the description of the Holy Spirit Hospital and St George Hospital. The report also covers the issue of the church endowment. The parish land was leased by five people at the time: mayor Andrzej Wesler, town councillor Kazimierz Lighton, church administrator Józef Wax, town inhabitant Franciszek Kobwald and two widows: Anna Plastwich and Anna Hohsmann. A great deal of information included in the report, especially personal details, has not been mentioned in the literature so far; this means that this material broadens our knowledge about the parish and church in Orneta.
\end{abstract}

Key words: the diocese of Warmia; Orneta; a parish; a church; monuments; priests; church employees 